\title{
MODIFIKASI PERILAKU MEROKOK MELALUI STRATEGI PERUBAHAN MINDSET REALITAS SEBAGAI PENOPANG MUTU PEMBELAJARAN
}

\author{
Yang Gustida Aditya Jakti \\ UPT SMP Negeri 2 Kota Mojokerto \\ Email : yang_gustida@yahoo.com
}

\begin{abstract}
ABSTRAK
Salah satu permasalahan siswa yang cukup serius dalam dunia pendidikan saat ini adalah perilaku merokok. Selain menghambat peningkatan mutu pembelajaran dan merusak kesehatan, perilaku merokok merepresentasikan tingkat copying siswa terhadap lingkungan pergaulannya. Saat ini, perilaku merokok dilakukan oleh siswa sebagai cara instan untuk memperoleh pengakuan dan mengisi waktu luang. Penelitian ini ditujukan untuk memodifikasi perilaku merokok melalui strategi perubahan mindset realitas kepada siswa kelas IX F-J yang teridentifikasi sebagai perokok aktif. Data penelitian diperoleh melalui observasi, wawancara dan tes yang dianalisis menggunakan metode deskriptif kuantitatif. Penelitian diberikan dalam bentuk konseling individu serta didukung layanan informasi. Berdasarkan data penelitian, perilaku merokok secara aktif dilakukan oleh 3 siswa. Perilaku merokok diawali keinginan coba-coba. Sebelum perlakuan, ketiga siswa merokok dalam sehari menghabiskan antara 1-5 batang. Setelah perlakuan, frekuensi merokok mulai berkurang secara bertahap hingga akhirnya menjadi 1 batang per dua hari. Ketiga siswa mampu memodifikasi perilaku merokok menjadi tidak merokok dalam waktu 3-5 bulan. Data penelitian juga menunjukkan terjadinya perilaku maladaptif ketiga siswa ketika di kelas yang menyebabkan pembelajaran tidak optimal. Setelah perlakuan diberikan, perilaku maladaptif menjadi berkurang dan terkontrol. Dengan demikian, strategi perubahan mindset realitas mampu memodifikasi perilaku merokok serta mampu menjadi penopang suksesnya proses pembelajaran. Kata Kunci : modifikasi; perilaku merokok; perubahan mindset realitas; mutu pembelajaran
\end{abstract}

\begin{abstract}
One of the students serious problems in the educational world today is the smoking behavior. In addition to inhibiting improved quality of learning and destructive health, smoking behaviors constitute the level of copying students to their environmental environment. Nowadays, smoking behaviour is done by students as an instant way to get recognition and fill free time. The study aims to modify the behavior of smoking through a reality change strategy mindset for the IX class F-J students identified as active smokers. Research Data is obtained through observations, interviews and tests analyzed using quantitative descriptive methods. Research is provided in the form of individual counseling as well as supported information services. Based on the research data, the behavior of smoking is actively conducted by 3 students. The smoking behavior begins to try to try. Before treatment, all three students smoked in one day were spent between 1-5 rods. After treatment, the frequency of smoking began to decline gradually until it finally became 1 rod per two days. All three students can modify the behavior of smoking to not smoke within 3-5 months. Research Data also shows the occurrence of behavior of third maladaptive students when in the classroom that causes learning is not optimal. After treatment is administered, maladaptive behavior becomes reduced and controlled. Thus, the reality of changing a strategy mindset is capable of modifying smoking behaviour as well as being able to support the success of the learning process.
\end{abstract}

Keyword : Modification ; Smoking behavior ; change of reality mindset ; Learning Qualty 


\section{PENDAHULUAN}

Masa SMP merupakan fase perkembangan remaja yang sangat rentan dan labil. Pada masa ini banyak remaja mencari jati diri untuk membentuk suatu pemikiran serta mencari pengakuan dari orang-orang disekitarnya. Berdasarkan pengalaman penulis secara langsung serta data yang teridentifikasi di lingkungan SMP 2, terdapat masalah siswa yang sangat penting dan perlu penyelesaian secara cepat dan tepat. Masalah tersebut adalah perilaku merokok pada siswa. Perilaku merokok merupakan salah satu perilaku maladaptif. Oleh karena itu, penting untuk ditangani karena berpotensi merugikan diri sendiri dan orang lain. Hal tersebut diperkuat oleh Abidin (Abidin, 2010, hal. 179) yang mengemukakan bahwa perilaku maladaptif merupakan bentuk tindakan yang mampu merugikan diri sendiri maupun orang lain.

Menurut Sitepoe (Yuni Sanjiwani \& Wulan Budisetyani, 2014, hal. 345), perilaku merokok merupakan tindakan yang dilakukan seseorang dengan melakukan pembakaran tembakau yang kemudian dihisap asapnya, baik menggunakan rokok maupun pipa. Lebih lanjut, Karyadi (Yuni Sanjiwani \& Wulan Budisetyani, 2014, hal. 345) mengutarakan bahwa Indonesia menduduki peringkat ke-4 jumlah perokok terbanyak di dunia dengan jumlah sekitar 141 juta orang. Terdapat sebanyak 57 ribu perokok meninggal dan 500 ribu menderita berbagai penyakit. Berdasarkan pemahaman tersebut, diketahui bahwa merokok mampu menghasilkan sesuatu yang mengganggu kesehatan menimbulkan berbagai hal negatif. Baik terhadap diri sendiri maupun orang lain.

Penelitian ini berfokus pada strategi yang berasal dari penerapan konseling realitas dan layanan informasi untuk memodifikasi perilaku merokok. Menurut hasil penelitian Adi Winarni (Adi Winarni, 2017, hal. 22), diketahui bahwa pendekatan realitas mampu mengatasi masalah penerimaan diri yang rendah. Berdasarkan hasil penelitian tersebut, maka treatment yang penulis lakukan dapat menjadi suatu langkah nyata akan peran Bimbingan dan Konseling terhadap peningkatan mutu pembelajaran, khususnya dalam bidang pemahaman diri siswa.

Dalam penanganan perilaku merokok ini, penulis menerapkan konseling realitas dipadu layanan informasi mengenai rokok. Penanganan perilaku merokok tersebut merupakan modifikasi perilaku. Menurut konteks bahasa (Kemdikbud, 2017), modifikasi merupakan suatu pengubahan atau perubahan. Dengan demikian, modifikasi perilaku dalam penelitian ini merupakan proses pengubahan perilaku siswa menjadi lebih adaptif.

Konseling realitas diterapkan karena berfokus pada perilaku saat ini. Selain itu, teknik konseling realitas merupakan bentuk modifikasi perilaku yang penerapannya tidak rumit (Corey, 2011, hal. 263-264). Lebih lanjut, Corey menyatakan dalam strategi tersebut, diterapkan teknik analisis 3R, yakni Responsibility, Reality dan Right. Untuk treatment, diterapkan tahapan yang berupa penguatan perilaku, modelling dan melemahkan perilaku.
Penerapan konseling akan diterapkan bersama layanan informasi. Hal tersebut mengacu kepada Winkel (Hidayati, 2015, hal. 4), yang menyatakan bahwa penerapan layanan informasi tersebut sebagai upaya agar siswa mampu menerima dan memahami berbagai informasi. Layanan informasi disampaikan secara klasikal sebagai bentuk pemahaman teoritis.

Berdasarkan penjelasan tersebut, maka penelitian ini penting untuk dilakukan mengingat perilaku merokok merupakan salah satu permasalahan yang mampu mempengaruhi kualitas perilaku serta kepribadian siswa. Dengan adanya masalah terhadap siswa, maka dapat dipastikan peningkatan mutu pembelajaran akan terhambat. Hal tersebut dikarenakan perilaku maladaptif siswa mampu menjadi efek domino terhadap proses pembelajaran apabila tidak disikapi serta ditangani dengan serius.

Peningkatan mutu pembelajaran yang terjadi saat ini lebih banyak terfokus pada bidang akademik. Meskipun demikian, perlu adanya peningkatan yang sinergis terhadap aspek non akademik. Hal tersebut penting dilakukan mengingat masih terdapat permasalahan siswa yang membutuhkan tindakan kuratif serta rehabilitatif.

Berdasarkan hal tersebut,maka penelitian dengan judul Modifikasi Perilaku Merokok Melalui Strategi Perubahan Mindset Realitas Sebagai Penopang Mutu Pembelajaran ini perlu dilakukan.

\section{METODE}

Desain Penelitian

Penelitian ini merupakan penelitian preeksperimental (nondesign) dengan metode deskriptif kuantitatif. Bentuk desain penelitian ini menggunakan desain penelitian tindakan one-group pretest-postest design. Rancangan ini tidak ada kelompok pembanding (kontrol). Hal tersebut dikarenakan sudah dilakukan pengambilan data pertama (pretest) yang memungkinkan menguji perubahan-perubahan yang terjadi setelah adanya eksperimen. Proses dasar penelitian tindakan tersebut ditunjukkan

pada gambarbaganl.

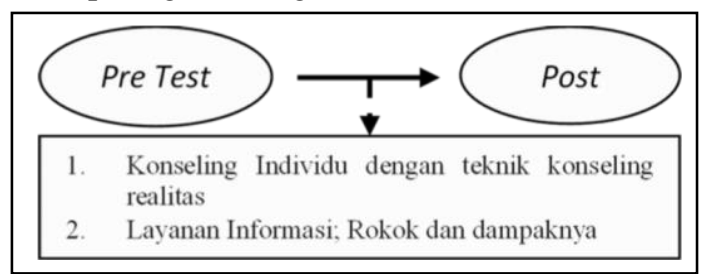

Bagan1. Konsep DasarPenelitian

Subjek dan Objek Penelitian

Subjek dalam penelitian ini adalah siswa asuh kelas IX yang teridentifikasi sebagai perokok aktif. Teknik sampling dilakukan secara purposive sampling. Dalam penelitian ini, pertimbangan didasarkan atas rekomendasi guru.

Objek dalam penelitian ini mengarah kepada modifikasi perilaku merokok dan strategi perubahan mindset realitas. 
Instrumen Pengumpulan Data Dalam penelitian tindakan ini, terdapat beberapa instrumen pengumpulan data yang terdiri atas instrumen tes, observasi dan wawancara. Instrumen tersebut diharapkan mampu mendukung ketepatan penelitian tindakan ini. Secara ringkas, instrumen pengumpulan data mencakup data yang tercantum dalam tabel 1 .

Tabel 1

Instrumen Penelitian

\begin{tabular}{|c|c|c|}
\hline No. & Metode & Data yang Diharapkan \\
\hline 1. & $\begin{array}{l}\text { Tes / } \\
\text { Kuesioner }\end{array}$ & \begin{tabular}{llr} 
a. & \multicolumn{2}{l}{ Latar belakang perilaku } \\
& merokok; \\
b. Jenis rokok yang & \\
& dihisap; & \\
c. & Frekuensi dan \\
& merokok; \\
d. & Situasi r \\
& mendorong & \\
& merokok; & \\
e. & Sensasi yang dirasakan \\
& ketika merokok;
\end{tabular} \\
\hline 2. & Observasi & $\begin{array}{l}\text { Bentuk perilaku merokok } \\
\text { beserta dampaknya } \\
\text { terhadap siswa dalam } \\
\text { kegiatan sehari-hari. }\end{array}$ \\
\hline 3. & Wawancara & \begin{tabular}{lll} 
a. & \multicolumn{2}{l}{ Siswa-siswa yang } \\
& teridentifikasi sebagai \\
& perokok aktif; \\
b. & Gambaran perilaku \\
& siswa yang merokok \\
& ketika di kelas; \\
c. & Faktor-faktor yang \\
& menyebabkan siswa \\
& merokok; \\
d. & Dampak yang \\
& ditimbulkan perilaku \\
& merokok terhadap \\
& siswa.
\end{tabular} \\
\hline
\end{tabular}

A. Teknik Analisis Data

Dalam penelitian ini digunakan statistik deskriptif karena penulis hanya ingin mendeskripsikan data yang telah terkumpul sebagaimana adanya tanpa bermaksud membuat kesimpulan yang berlaku untuk umum atau generalisasi.

1. Analisis Tes

Data angket yang berupa hasil pre-test dan post-test akan dianalisis menggunakan analisis prosentase peningkatan. Prosentase peningkatan tersebut untuk mengetahui ada tidaknya peningkatan dari sebelum tindakan (pretest) dibandingkan dengan data setelah tindakan (post-test).

2. Analisis Hasil Observasi. Mendeskripsikan kondisi dan aktivitas siswa yang teridentifikasi sebagai perokok aktif dengan mengacu kepada check list yang telah dibuat.

3. Analisis Hasil Wawancara Mendeskripsikan berbagai pandangan mengenai perilaku merokok yang dilakukan oleh siswa.

\section{HASIL DAN PEMBAHASAN}

\section{A. HASIL PENELITIAN}

1. Data Tes/Kuesioner

Berdasarkan hasil tes/kuesioner, diperoleh data yang menunjukkan Mamad memperoleh skor perilaku merokok sebesar 154, Eep memperoleh skor 168 dan Sobri memperoleh 127. Berdasarkan data pre test, diketahui bahwa perilaku merokok yang dimiliki subjek penelitian berbeda. Secara prosentase, perilaku merokok tertinggi diperoleh Eep dengan 84\%, Mamad 77\% dan Sobri 64\%. Lebih jelas, data digambarkan pada diagram 1 .

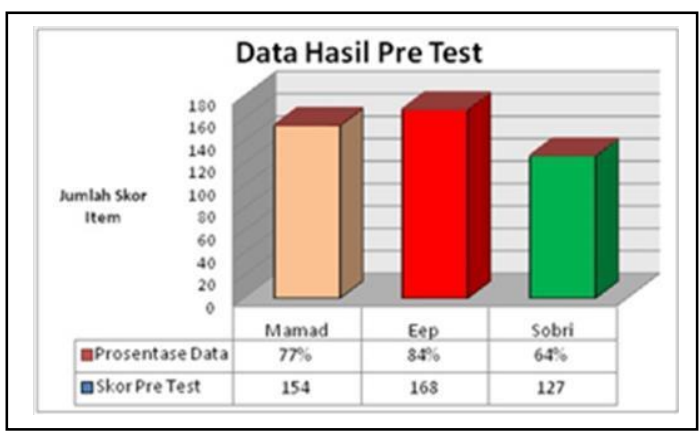

Diagram . Data Hasil Pre Test

Setelah diberikan perlakuan, diperoleh data baru. Berdasarkan data post test, diperoleh hasil yang menunjukkan tren penurunan skor perilaku merokok yang diperoleh ketiga siswa. Data hasil post test lebih jelas digambarkan pada diagram 2.

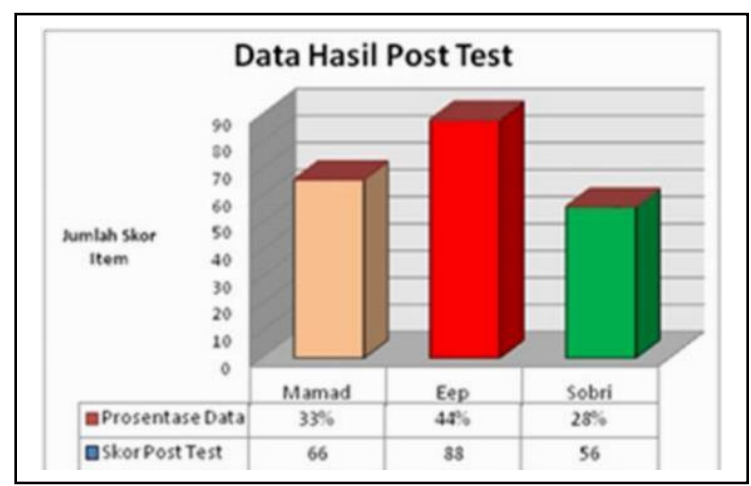

Diagrana . Data Hasil Post Test

2. Data Observasi 
Kegiatan observasi dilakukan penulis selama berada di lingkungan sekolah. Penulis mengobservasi para siswa tersebut pada waktu jam istirahat, pemberian layanan klasikal, ketika sedang mengikuti KBM, dan sepulang sekolah selama masih berada di lingkungan sekitar sekolah.

Berdasarkan observasi, teridentifikasi banyak persamaan dari ketiga siswa. Secara umum, ketiga siswa memiliki bibir yang gelap tidak sehat, kulit kusam kurang sehat, mata merah, gigi kekuningkuningan dengan sedikit bercak, sering batuk, nafas kurang kuat ketika olahraga, sering gelisah, mudah bimbang, menyukai aroma rokok, lihai memegang rokok, mulut cederung kurang nyaman setelah makan, dan agresif secara verbal.

3. Data Wawancara

Dalam penelitian ini, wawancara dilakukan secara tak terstruktur dengan tujuan untuk memperoleh data yang lebih terbuka. Secara garis besar, diketahui bahwa Mamad pernah tertangkap oleh guru sedang merokok di sekolah. Untuk Eep dan Sobri cenderung merokok di luar sekolah. Selain itu, mereka cenderung tidak bisa tenang di kelas, cenderung usil, agresif secara verbal, kurang disiplin dan kurang semangat. Mengenai nilai akademis, mereka bertiga memiliki nilai yang cenderung kurang, padahal mereka sebenarnya memiliki kemampuan untuk lebih.

Lebih lanjut, berdasarkan wawancara dan hasil konseling diketahui bahwa perilaku merokok tersebut disebabkan oleh faktor pergaulan, keluarga yang terlalu sibuk, adanya uang saku yang lebih, sering di warung kopi, dan keinginan untuk mencoba. Selain itu, terdapat banyak dampak merokok yang merugikan. Diantaranya masalah kesehatan dan nilai akademik yang kurang optimal akibat banyak bermain serta berinteraksi di warung kopi atau sejenisnya.

\section{B. Pembahasan Hasil Penelitian}

Penelitian ini merupakan penelitian deskriptif kuantitatif dengan desain pre eksperimental (nondesign) yang menerapkan jenis desain one-group pretest-postest design. Pada dasarnya penelitian ini memiliki kelemahan, yakni tergolong penelitian yang kurang sempurna akibat tidak adanya kelompok pembanding.

Berdasarkan data pemberian angket, observasi dan wawancara, diperoleh perbedaan antara sebelum dan sesudah perlakuan. Perlakuan diberikan melalui strategi perubahan mindset realitas dengan rincian 4 kali perlakuan konseling dan 2 kali pemberian layanan informasi. Dalam pemberian perlakuan tersebut, frekuensi merokok siswa ditekan secara bertahap dalam setiap perlakuan sehingga pada akhirnya mampu dihilangkan atau diganti dengan media lain seperti permen.

Berdasarkan hasil analisis, diketahui perilaku merokok dipengaruhi keinginan cobacoba, latar belakang kondisi keluarga, pergaulan, dan adanya uang saku yang lebih.

Lebih lanjut, salah satu faktor penyebab merokok adalah rendahnya menerima kondisi diri. Akibat adanya penerimaan diri yang rendah, siswa melampiaskan kepada perilaku merokok. Namun demikian, pemberian strategi perubahan mindset realitas mampu membantu meningkatkan penerimaan diri yang rendah sehingga berdampak pada berkurangnya frekuensi merokok.

Mengacu kepada latar belakang masalah, diketahui bahwa siswa memiliki informasi yang kurang mengenai rokok. Dengan pemahaman yang kurang, maka perilaku merokok mendapat pembenaran. Akan tetapi, setelah perlakuan, siswa menjadi lebih paham mengenai rokok beserta dampaknya. Dengan demikian dapat disimpulkan bahwa siswa mampu belajar secara tidak langsung mengenai rokok.

Berdasarkan analisis data pretest dan postest, diketahui perbedaan data antara sebelum dan sesudah perlakuan menggunakan strategi perubahaan mindset realitas. Perbedaan tersebut cenderung mengarah kepada terjadinya penurunan perilaku merokok.

Tabel 2. Perbedaan Hasil Pre Test dan

Post Test

\begin{tabular}{|l|l|l|l|l|}
\hline A & B & C & D & E \\
\hline Eep & $84 \%$ & $44 \%$ & $40 \%$ & $48 \%$ \\
\hline Mamad & $77 \%$ & $33 \%$ & $44 \%$ & $57 \%$ \\
\hline Sobri & $64 \%$ & $28 \%$ & $36 \%$ & $56 \%$ \\
\hline \multicolumn{5}{|c}{ Keterangan : }
\end{tabular}
A. Subjek
B. Hasil Pre Test
C. Hasil Post Test
D. Jumlah Penurunan
E. Prosentase Penurunan

Berdasarkan tabel hasil pre test dan post test tersebut, maka dapat diketahui bahwa terjadi penurunan yang cukup jelas antara sebelum dan sesudah perlakuan. Dengan demikian, maka dapat disimpulkan bahwa strategi perubahan mindset realitas mampu dijadikan alternatif penyelesaian terhadap perilaku merokok siswa. Dalam penelitian ini, perilaku merokok termodifikasi karena rasa takut akan penyakit, adanya keinginan untuk sukses, adanya penyaringan pergaulan, dan mengganti rokok menggunakan permen.

Berdasarkan hal tersebut, maka dapat dipastikan bahwa pemberian strategi perubahan mindset realitas yang berakar pada konseling realitas dan layanan informasi mampu memodifikasi perilaku merokok siswa.

\section{PENUTUP}

\section{Simpulan}

Berdasarkan hasil penelitian dan analisisnya, diketahui bahwa terjadi perbedaan antara pretest dan 
postest yang diberikan kepada siswa yang teridentifikasi sebagai perokok aktif. Perubahan hasil tersebut terjadi setelah diberikan perlakuan strategi perubahan mindset realitas. Dalam strategi tersebut, terdapat konseling realitas yang diberikan dengan menerapkan teknik analisis 3R, yakni Responsibility, Reality dan Right. Untuk treatment, diterapkan tahapan konseling realitas yang berupa penguatan perilaku (shaping, behavioral contract, assertive training), modelling (symbolic model) dan melemahkan perilaku (extinction, reinforcing incompatible behavior).

Dengan demikian, dapat disimpulkan bahwa modifikasi perilaku merokok siswa dapat dilakukan melalui strategi perubahan mindset realitas yang terdiri atas gabungan konseling realitas dan layanan informasi mengenai rokok yang diberikan secara klasikal.

Dampak pemberian strategi perubahan mindset realitas mengarah kepada kondisi kesehatan serta perilaku sehari-hari siswa. Setelah diberikan perlakuan, siswa menjadi lebih sehat, mampu menyaring lingkungan pergaulan, mampu memahami lebih jauh tentang rokok serta bahayanya. Dampak tersebut cenderung berbeda antara siswa satu dengan yang lain. Untuk Eep, perilaku merokok tidak lagi dilakukan setelah 5 bulan perlakuan diberikan. Mamad cenderung lebih cepat, yakni setelah perlakuan terakhir diberikan. Hal tersebut dapat terjadi karena

Mamad mengganti rokok dengan permen. Untuk Sobri, mampu untuk tidak merokok lagi setelah informasi tentang rokok diberikan. Faktor yang membuat dirinya lebih cepat melepas rokok yakni munculnya rasa takut terhadap berbagai penyakit akibat perilaku merokok.

\section{DAFTAR PUSTAKA}

Abidin, Z. (2010). Konseling Sebagai Alternatif Penanggulangan Perilaku Maladaptif Remaja Deprivasi Parental. Komunika , IV, 178-192.

Adi Winarni, M. (2017). Efektivitas Konseling Realitas Untuk Meningkatkan Penerimaan Diri Siswa Kelas IX SMP Negeri 1 Tempel. E-Journal Bimbingan dan Konseling , 1, 1023.

Corey, G. (2011). Teori dan Praktek Konseling \& Psikoterapi. Bandung: PT. Refika Aditama.

Hidayati, R. (2015). Layanan Informasi Karir

Membantu Peserta Didik Dalam Meningkatkan Pemahaman Karir. Jurnal Konseling Gusjigang , I.

Kemdikbud, (. B. (2017). 2.0. Dipetik Agustus 29, 2017, dari KBBI Daring (Dalam Jaringan / Online): https://kbbi.web.id/modifikasi Yuni Sanjiwani, N. L., \& Wulan Budisetyani, I. G. (2014). Pola Asuh Permisif Ibu dan Perilaku Merokok Pada Remaja Laki-Laki di Sma Negeri 1 Semarapura. Jurnal Psikologi Udayana , I, 344352. 